\title{
PENERAPAN METODE QIRO'ATI DALAM MENINGKATKAN KEFASIHAN MEMBACA AL-QUR'AN SISWA KELAS VI MADRASAH IBTIDAIYAH PONDOK PESANTREN RAUDHATUL ULUM SAKATIGA KECAMATAN INDRALAYA KABUPATEN OGAN ILIR
}

\author{
Komputri Apria Santi \\ Sekolah Tinggi Ilmu Tarbiyah Raudhatul Ulum Sakatiga \\ Email: fathir_kholilatie@yahoo.co.id
}

\begin{abstract}
Abstrak
Keberhasilan suatu program, terutama pengajaran dalam proses belajar mengajar tidak terlepas dari pemilihan metode. Metode adalah seperangkat cara, jalan dan teknik yang digunakan oleh pendidikan dalam proses pembelajaran agar peserta didik dapat mencapai tujuan pembelajaran atau menguasai kompetensi tertentu yang dirumuskan dalam silabus mata pelajaran. Dan disini banyak sekali metode yang digunakan, yang tujuannya untuk meningkatkan kemampuan belajar anak. Akan tetapi metode yang digunakan tidak selalu cocok untuk peserta didik karena kadang-kadang metode yang digunakan tidak sesuai dengan keadaan peserta didik. Oleh karena itu metode qiroati sangatlah berpengaruh dalam sistem belajar mengajar terutama dalam pelajaran al-Qur'an. Penelitian ini mengangkat masalah, Bagaimana penerapan metode qiro'ati siswa kelas VI Madrasah Ibtidaiyah Pondok Pesantren Raudhatul Ulum Sakatiga Ogan Ilir?

Jenis penelitian yang digunakan adalah penelitian kuantitatif. Sedangkan teknik analisis data menggunakan uji statistik (kuantitatif).Pengumpulan data dilakukan dengan teknik observasi, wawancara, dokumentasi serta kuesioner (angket) dan metode tes prestasi. Kemudian sumber data yang digunakan yaitu data primer dan data sekunder. Objek dalam penelitian ini adalah guru alQur'an, dan 43 orang siswa sebagai responden.

Setelah melakukan proses pengumpulan data dan analisis data, maka diperoleh kesimpulkan bahwa, Penerapan metode qiro'ati dalam meningkatkan kefasihan membaca al-Qur'an siswa kelas VI MI Raudhatul Ulum Sakatiga adalah 11 orang responden tinggi (25,58\%), 28 orang responden sedang (65,11\%). Dan 4 orang responden rendah (9,30\%). Maka dapat dikatakan bahwa penerapan metode qiro'ati dalam meningkatkan kefasihan membaca al-Qur'an adalah dalam kategori sedang yaitu (65,11\%). Dan kefasihan membaca al-Qur'an siswa kelas VI Madrasah Ibtidaiyah Raudhatul Ulim Sakatiga adalah 5 orang responden tingi (11,62\%), 35 orang responden sedang (81,39\%). dan 3 orang responden rendah (6,97\%). Maka dapat dikatakan bahwa kefasihan siswa kelas VI Madrasah Ibtidaiyah Raudhatul Ulum Sakatiga Indralaya adalah dalam kategori sedang karena dari 43 siswa sebanyak 35 siswa atau 81,39\% yang mendapatkan skor dengan kualifikasi sedang.
\end{abstract}

Kata Kunci: Metode Qiro'ati, Al-Qur'an, Siswa, Rauhdatul Ulum 


\section{Penrapan Metode Qiro'ati Dalam Meningkatkan Kefasihan Membaca Al-Qur'an Siswa Kelas VI Madrasah Ibtidaiyah Pondok Pesantren Raudhatul Ulum Sakatiga Kecamatan Inderalaya Kabupaten Ogan Ilir \\ Komputri Apria Santi \\ Pendahuluan}

Pendidikan sangatlah penting dalam kehidupan, tanpa adanya pendidikan seorang anak tidak bisa berkembang. Pendidikan adalah bagian dari upaya untuk membantu manusia memperoleh kehidupan yang bermakna hingga diperoleh suatu kebahagian hidup, baik secara individu maupun kelompok.

Dewasa ini pengaruh kebudayaan barat yang negatif berkembang pesat melalui berbagai macam cara, seperti: film, surat kabar, majalah, televisi dan sebagainya. Maka Ilmu Pendidikan Islam mempunyai tugas dan tanggung jawab agar anak didik tetap memiliki akhlak mulia dan tidak terpengaruh oleh kebudayaan asing yang bertentangan dengan nilai dan norma Islam. ${ }^{1}$

Semua tujuan pendidikan, baik pendidikan umum maupun pendidikan agama selalu mengidealkan terciptanya sikap anak didik yang dewasa, baik intelektualnya, emosionalnya, maupun spiritualnya. Proses pendidikan yang hanya menekankan kedewasaan intelektual dan mengabaikan kedewasaan emosional dan spiritual akan memunculkan manusia yang cerdas tetapi tidak bermoral, intoleran, miskin solidaritas, dan tidak humanis.

Untuk mencapai kebahagian hidup di dunia perlu dipenuhi kebutuhan-kebutuhan duniawi seperti sandang, pangan, dan papan serta berbagai sarana kemudahan hidup. Semua itu akan terpenuhi apabila orang yang bersangkutan memiliki berbagai kemampuan untuk memperolehnya, berupa ilmu dan berbagai keterampilan teknis. Begitu pula untuk mencapai kebahagian akhirat, dia memerlukan ilmu, dengan demikian kedua tujuan pendidikan tertinggi tersebut hanya akan dapat dicapai dengan ilmu. ${ }^{2}$

Untuk dapat membina akhlak pembelajaran al-Quran terhadap anak sebagai salah satu pembinaan akhlak perlu secara terus menerus mengembangkan diri secara sistematis. Umat Islam sekarang hidup pada abad yang disinari oleh pengetahuan yang telah dicapai oleh orang-orang Eropa dan Amerika terutama dalam bidang teknologi. Umat Islam lupa bahwa mereka mempunyai al-Quran yang merupakan kitab suci yang telah memberikan pengaruh begitu luas dan mendalam terhadap jiwa manusia.

Al-Quran merupakan dasar keyakinan yang keagamaan, keibadahan dan hukum. Membimbing manusia dalam mengarungi hidupnya adalah sangat layak bila al-Quran mendapat perhatian istimewa.Disisi lain ada gejala yang cukup menggembirakan bahwa arus kesadaran untuk mengaji al-Quran secara bersungguh-sungguh mulai mengalir dan tumbuh dikalangan intelektual dan orang-orang mudah terpelajar. Kesadaran ini pula pada gilirannya mendorong mereka ke tempat pengajian atau mereka malah mengundang guru agama ke rumah mereka.

Pendidikan baik itu orang tua, pengajar atau guru dan pula pemimpin atau pemuka masyarakat, sebenarnya adalah perantara atau penghubung aktif yang menjembati antara anak didik dengan tujuan pendidikan yang telah dirumuskan. Tanpa pendidik, tujuan pendidikan manapun yang telah dirumuskan tidak akan dapat dicapai oleh anak didik. ${ }^{3}$ Untuk itu guru bertanggung jawab mendidik dan memberikan penguatan-penguatan yang baik dan positif untuk kehidupannya.

Pada dasarnya, manusia diciptakan oleh Allah SWT dalam keadaan fitrahdan memiliki berbagai potensi atau kelebihan dibandingkan makhluk yang lain.Kelebihan pertama, manusia diciptakan oleh Allah dengan bentuk yang palingsempurna (Ahsanat-Taqwim). Kelebihan kedua, manusia dianugerahi akal olehAllah SWT dan dengan akal itulah manusia

\footnotetext{
${ }^{1}$ M. Sudiyono, Ilmu pendidikan Islam Jilid I, (Jakarta: PT Rineka Cipta, 2009), h. 13

${ }^{2}$ Ibid., h. 39

${ }^{3}$ Abu Ahmadi, Nur Uhbiyati, IlmuPendidikan, (Jakarta: PT Rineka Cipta, 2003), h. 242
} 
Volume 3 Nomor 2 Edisi Desember 2018

P-ISSN : 2541-3686

dapat memiliki ilmu dan potensiberagama serta membedakan mana yang haq dan mana yang bathil. Kelebihanketiga, manusia dianugerahi nafsu oleh Allah. Dengan nafsu itulah manusia dapathidup dan menjalankan fungsi sebagaimana mestinya. Kelebihan keempat,manusia dianugerahi Allah berupa hati nurani (qolbu), yang berfungsi sebagaipenengah antara akal dan nafsu. Kelebihan kelima, manusia di beri kebebasanuntuk menentukan pilihan, dalam hal apapun, kecuali takdir Allah. ${ }^{4}$

Dari beberapa kelebihan diatas, telah jelas bahwasanya kewajiban manusiaselama hidup di dunia hanyalah semata-mata untuk menyembah-Nya dan meyakini bahwa al-Qur'an merupakan lambang agama Islam yang paling asasidan hakiki sebagai pedoman bagi seluruh umat manusia.Oleh karena itu, setiap manusia hendaknya senantiasa mempelajari al-Qur'an dan mengajarkannya kepada manusia yang lain. Aktifitas belajar al-Qur'an merupakan aktifitas positif yang diberikan kepada seluruh umat manusiasebagai ungkapan apresiasi luar biasa oleh Rasulullah SAW, sebagaimana beliau bersabda:

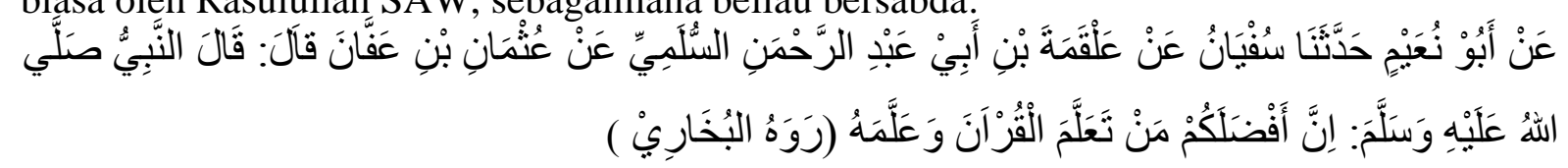

"Dari Abu Nu'aimi Sofyan berkata dari Alqomah bin Abi Abdirrahman As-Sulami dari Utsman bin Affan berkata, Rasulullah SAW bersabda: "Seutama-utamakalian adalah orang yang belajar al-Qur'an dan mengajarkannya". (HR. Bukhori). ${ }^{5}$

Keberhasilan suatu program, terutama pengajaran dalam proses belajar mengajar tidak terlepas dari pemilihan metode. Dan disini banyak sekali metode yang digunakan. Yang tujuannya untuk meningkatkan kemampuan belajar anak. Akan tetapi metode yang digunakan tidak selalu cocok untuk peserta didik karena kadang-kadang metode yang digunakan tidak sesuai dengan keadaan peserta didik.

Adapun salah satu model pembelajaran al-Qur'an yang menggunakan metode praktis yang dapat mengantarkan anak mampu membaca al-Qur'an sesuai dengan kaidah-kaidah yang telah ditentukan adalah dengan menggunakan metode qiro'ati. Metode ini merupakan metode pembaharu dari metode membaca al- Qur'an sebelumnya. Dalam metode ini lebih menekankan pada pendekatan ketrampilan proses yaitu pada ketepatan membaca, Makharijal-Huruf, GhoribMusykilat maupun tajwidnya secara benar dan fasih.

Dengan diterapkannya metode qiro'ati ini siswa diajari al-Qur'an secara langsung tanpa harus dieja, sehingga siswa tidak hanya menghafal tetapi juga mudah dalam mengingat apa yang telah diajarkan kepada mereka serta dapat membaca al-Qur'an secara benar dan fasih.Salah satu lembaga pendidikan Sekolah Dasar/Madrasah Ibtidaiyah yang menerapkan metode qiro'ati yaitu Madrasah Ibtidaiyah Raudhatul ulum (MIRU) Sakatiga Indralaya.

\section{Metodologi Penelitian}

Metode penelitian adalah cara-cara yang dapat digunakan oleh peneliti untuk mengumpulkan data. ${ }^{1}$ Sedangkan menurut Beni Ahmad Saebani, metode penelitian adalah metode yang digunakan dalam aktivitas penelitian. ${ }^{2}$ Jenis penelitian ini adalah kuantitatif yang bersifat eksperiment, meliputi tentang penerapan metode qiro'ati. Metode yang digunakan adalah metode observasi, metode angket, dan metode dokumentasi

\footnotetext{
${ }^{4}$ Heri Jauhari Muchtar, Fikih Pendidikan, (Bandung: Remaja Rosdakarya, 2005), h. 7-10

${ }^{5}$ Ibnu Hajar Al-Atsqolani, FathulBaari: Bi Syarh Shahih Al-Bukhori, (diterjemahkan oleh Amirudin), (Jakarta: Pustaka Azam, 2002), Jilid 9, h. 89

${ }^{1}$ Suharsimi Arikunto, Manajemen Penelitian, (Jakarta: Rineka Cipta, 2010), h. 100

${ }^{2}$ Beni Ahmad Saebani, Metode Penelitian, (Bandung: Pustaka Setia, 2008), h. 43
} 


\section{Penrapan Metode Qiro'ati Dalam Meningkatkan Kefasihan Membaca Al-Qur'an}

Siswa Kelas VI Madrasah Ibtidaiyah Pondok Pesantren Raudhatul Ulum Sakatiga Kecamatan Inderalaya Kabupaten Ogan Ilir

\section{Komputri Apria Santi}

1. Metode observasi; metode ini, merupakan suatu metode pengumpulan data, dengan cara pengamatan dan pencatatan secara sistematis, mengenai fenomena yang diselidiki. ${ }^{3}$ Dalam penelitian ini peneliti menggunakan observasi partisipatif dan bersifat partisipatif pasif.Dalam observasi ini, penelliti terlibat dengan kegiatan sehari-hari orang yang sedang diamati atau yang digunakan sebagai sumber data peneliti. Sambil melakukan pengamatan, peneliti ikut melakukan apa yang dikerjakan oleh sumber data, dan ikut merasakan suka dukanya. ${ }^{4}$ Dengan observasi partisipan ini, maka data yang diperoleh akan lebih lengkap, tajam, dan sampai mengetahui pada tingkat makna dari setiap perilaku yang nampak. Observasi pasif adalah peneliti datang di tempat kegiatan orang yang yang diamati, tetapi tidak ikut terlibat dalam kegiatan tersebut. ${ }^{5} \mathrm{Jadi}$ peneliti hanya mengamati pelaksanaan metode qiroati.

2. Metode Kuesioner (Angket); metode kuesioner merupakan teknik pengumpulan data yang dilakukan dengan cara memberi seperangkat pertanyaan atau pertanyaan kepada responden untuk dijawabnya. ${ }^{6}$ Metode ini peneliti digunakan untuk mendapatkan data dengan cara mengajukan beberapa pertanyaan yang relatif jawabannya sudah tercantum. Metode ini digunakan untuk mengetahui seberapa jauh penerapan metode qiro'ati yangdiperoleh dari nilai siswa.

3. Metode dokumentasi; metode ini digunakan untuk memperoleh catatan, transkrip, buku, surat kabar, data dan sebagainya. ${ }^{7}$ Jadi metode ini, adalah metode pengumpulan data dengan cara mencari informasi, melalui dokumentasi, arsip-arsip, buku-buku catatan dan lainnya terkait dengan data yang dibutuhkan seperti yang diungkap di atas, yaitu keadaan sekolah, silabus, dan RPP.Metode dokumentasi ini dilakukan sebagai bahan banding untuk mendukung atau meningkatkan kepercayaan hasil data yang dikumpulkan melalui metode observasi dan angket tentang pelaksanaan metode qiroati.

Untuk menganalisis data dalam penelitian ini maka penulis menggunakan teknik analisis statistik. Data yang diperoleh masing-masing variabel angket adalah data kuantitaif atau jawaban responden yang sudah berbentuk angka sehingga memungkinkan dalam menggunakan analisis statistik.

Setalah data dikumpulkan maka untuk mengetahui bagaimana pengaruh metode qiroati dalam kefasihan membaca al-qur'an siswa kelas VI di MIRU Sakatiga Ogan Ilir, maka akan dianalisis sebagai berikut:

1. Persentase, yaitu digunakan untuk memberikan interpretasi terhadap jawaban angket yang disebarkan dengan rumus:

$\mathrm{P}=\frac{\mathrm{f}}{\mathrm{N}} \mathrm{x} 100 \%$

Keterangan:

$\mathrm{P}=$ Persentasi

$\mathrm{F}=$ Frekwensi

$\mathrm{N}=$ Sampel $^{8}$

2. TSR, digunakan untuk mengklasifikasikan hasil jawaban angket yang disebarkan yaitu dengan menggunakan patokan sebagai berikut: ${ }^{9}$

${ }^{3}$ Arikonto, Manajemen, h. 133

${ }^{4}$ Sugiyono, Metode, h. 227

${ }^{5}$ Ibid., h. 227

${ }^{6}$ Sugiyono, Statistik Untuk Peneletian, (Bandung: Alfabeta, 2009), h. 157-166

${ }^{7}$ Suharsimi Arikunto, Prosedur Penelitian Suatu Pendekatan Praktik, (Jakarta: Rineka Cipta, 2006), h.

${ }^{8}$ Anas Sudijono, Pengantar Statistik Pendidikan, (Jakarta: PT Raja Grafindo Persada, 2010), h. 43
${ }_{9}^{9}$ Ibidt.,h. 176 


\begin{tabular}{|c|c|}
\hline$M+1 S D$ & \\
\hline$M-1 S D$ & \\
\hline
\end{tabular}

3. Analisis Regresi Linier Sederhana

Dengan menggunakan rumus Regresai linier sederhana yaitu:

$\mathrm{Y}=\mathrm{a}+\mathrm{bX}$

Keterangan:

Y : $\quad$ Subyek dalam variabel dependen yang diprediksikan.

A : $\quad$ Harga Y bila $\mathrm{X}=0$ ( harga konstan) .

$\mathrm{b}$ : $\quad$ Angka arah atau koefisien regresi, yang menunjukkan angka peningkatan atau penurunan variabel dependen yang didasarkan pada variabel independen. Bila b (+) maka naik, dan bila (-) maka terjadi penurunan.

$\mathrm{X}$ : $\quad$ Subyek pada variabel independen yang mempunyai nilai tertentu. ${ }^{10}$

\section{Hasil Pembahasan}

Untuk mengetahui lebih jelasnya tentang penerapan metode qiro'ati dalam meningkatkan kefasihan membaca al-Qur'an siswa kelas VI MIRU Sakatiga, peneliti mencoba menganalisa data hasil penelitian yang peneliti lakukan dengan perincian sebagai berikut:

1. Analisis Tentang Metode Qiro'ati.

Sebagaimana telah dijelaskan di atas, sebelum peneliti menyebar angket peneliti melakukan wawancara dahulu kepada guru al-Qur'an Madrasah Ibtidaiyah Raudhatul Ulum Sakatiga. Salah satu tujuan peneliti melakukan wawancara dengan guru al-Qur'an ialah untuk mengetahui apakah metode qiro'ati telah digunakan oleh guru al-Qur'an dan bagaimana cara metode qiro'ati dalam meningkatkan kefasihan membaca al-Qur'an siswa kelas VI Madrasah Ibtidaiyah Raudhatul Ulum Sakatiga.

Sebagaimana hasil wawancara dengan guru al-Qur'an Madrasah Ibtidaiyah Raudhatul Ulum Sakatiga pada tanggal 30-10-2012 beliau menerapkan:

"Ya, metode ini sudah dipakai oleh kita bahkan menjadi kewajiban bagi guru al-Qur'an untuk menggunakan metode ini, di dalam mengajar al-Qur'an kita menggunakan tiga metode, yang pertama tajwid, terus qiro'ati atau membaca atau yang sering kita dengar Qur'an tilawah dan yang terakhir hapalan atau tahfiz". ${ }^{11}$

Dari wawancara di atas dapat disimpulakan bahwa metode qiro'ati telah digunakan oleh guru al-Qur'an untuk memberikan materi terhadap siswa kelas VI Madrasah Ibtidaiyah Raudhatul Ulum.Dan untuk mengetahui bagaimana penerapan metode qiro'ati dalam meningkatkan kefasihan membaca al-Qur'an siswa kelas VI Madrasah Ibtidaiyah Raudhatul Ulum Sakatiga dapat dilihat dari hasil angket yang diuraikan berikut ini.

Kemudian hasil jawaban responden yang telah diberikan angket tersebut, selanjutnya direkapitulasi dan dianalisis dengan atatistik sebagai berikut:

Variabel X

78568078808078787474

75757880807576807178

\footnotetext{
${ }^{10}$ Sugiyono, Statistika untuk Penelitian, (Bandung: CV Alfabeta, 2005), h. 244

${ }^{11}$ Aidah, guru al-Qur'an Madrasah Ibtidaiyah Raudhatul Ulum Sakatiga, wawancara langsung pada hari selasa tanggal 30-10-2012, pukul 11. 30 wib.
} 
Penrapan Metode Qiro'ati Dalam Meningkatkan Kefasihan Membaca Al-Qur'an Siswa Kelas VI Madrasah Ibtidaiyah Pondok Pesantren Raudhatul Ulum Sakatiga Kecamatan Inderalaya Kabupaten Ogan Ilir

Komputri Apria Santi

78557478807664757578

76798080777676718070

807978

Distribusi Frekuensi Metode Qiroati

\begin{tabular}{|c|c|c|c|c|c|}
\hline $\mathrm{X}$ & $\mathrm{F}$ & $\mathrm{fX}$ & $\mathrm{X}$ & $\mathrm{x}^{2}$ & $\mathrm{Fx}^{2}$ \\
\hline \hline 80 & 11 & 880 & 4,21 & 17,72 & 194,92 \\
79 & 2 & 158 & 3,21 & 10,30 & 20,6 \\
78 & 10 & 780 & 2,21 & 4,88 & 48,8 \\
77 & 1 & 77 & 1,21 & 1,46 & 1,46 \\
76 & 5 & 380 & 0,21 & 0,04 & 0,2 \\
75 & 5 & 375 & $-0,79$ & 0,62 & 3,1 \\
74 & 3 & 222 & $-1,79$ & 3,20 & 5,37 \\
71 & 2 & 142 & $-4,79$ & 22,94 & 45,88 \\
70 & 1 & 70 & $-5,79$ & 33,52 & 33,52 \\
64 & 1 & 64 & $-11,79$ & 139,00 & 139,00 \\
56 & 1 & 56 & $-19,79$ & 391,64 & 391,64 \\
55 & 1 & 55 & $-20,79$ & 432,22 & 432,22 \\
Total & $\mathrm{N}=43$ & $\sum \mathrm{fx}=3259$ & $\sum \mathrm{x}=-54,48$ & $\sum \mathrm{x}^{2}=1057,54$ & $\sum \mathrm{fx}^{2}=1316,71$ \\
\hline
\end{tabular}

1) Mencari Mean-nya dengan rumus ${ }^{12}$ :

$$
\begin{aligned}
& M_{x}=\frac{\sum f x}{N} \\
& M_{x}=\frac{3259}{43} \\
& M_{x}=75,79
\end{aligned}
$$

Keterangan:

$\mathrm{Mx} \quad=$ Nilai rata-rata dari variable $\mathrm{x}$

$\sum \mathrm{fx} \quad=$ Jumlah hasil perkalian antara deviasi tiap-tiap interval $(\mathrm{X})$ dengan

Frekuensi masing-masing interval yang bersangkutan.

$\mathrm{N} \quad=$ Number of Cases

2) Mencari deviasi $x$ dengan rumus ${ }^{13}: x=X-M_{x}$

$$
\begin{aligned}
& x=X-M_{x} \\
& x=80-75,79 \\
& x=4,21
\end{aligned}
$$

12. Anas Sudijono, Pengantar Statistik.. h. 159

${ }^{13}$.ibid 158 
Keterangan:

$\mathrm{x}=$ Hasil dari pengurangan deviasi tiap-tiap interval (X) dengan nilai

Rata-rata dari masing-masing variable $\mathrm{x}$

$\mathrm{X}=$ Variabel $\mathrm{x}$

$\mathrm{M}_{\mathrm{x}} \quad=$ Nilai rata-rata dari variable $\mathrm{x}$

1) Menguadratkan $x$ sehingga diperoleh $x^{2}$, setelah itu di jumlahkan, sehingga diperoleh $\sum \mathrm{x}^{2}=1057,54$

2) Memperkalikan frekuensi dengan $x^{2}$, sehingga di peroleh $\sum f x^{2}$, setelah itu dijumlahkan, di peroleh $\sum \mathrm{fx}^{2}=1419,71$

3) Mencari SD-nya dengan rumus ${ }^{14}$ :

Keterangan:

$$
\begin{aligned}
& \mathrm{SD}_{\mathrm{x}}=\sqrt{\frac{\sum \mathrm{fx}^{2}}{\mathrm{~N}}} \\
& \mathrm{SD}_{\mathrm{x}}=\sqrt{\frac{1419,71}{43}} \\
& \mathrm{SD}_{\mathrm{x}}=\sqrt{33,01} \\
& \mathrm{SD}_{\mathrm{x}}=5,75
\end{aligned}
$$

$\mathrm{SD}_{\mathrm{x}} \quad=$ Deviasi standar $\mathrm{x}$

$\sum \mathrm{fx}^{2}=$ Jumlah hasil perkalian antara frekuensi masing-masing sekor,

Dengan deviasi sekor yang telah dikuadratkan.

$\mathrm{N} \quad=$ Number of Cases

Setelah di ketahui mean skor dan standar deviasi skor tentang nilai Pre-Test Siswa Kelas II a MI Raudhatul Ulum Ogan Ilir maka selanjutnya adalah menetapkan kategori TSR dengan menggunakan patokan sebagai berikut ${ }^{15}$ :

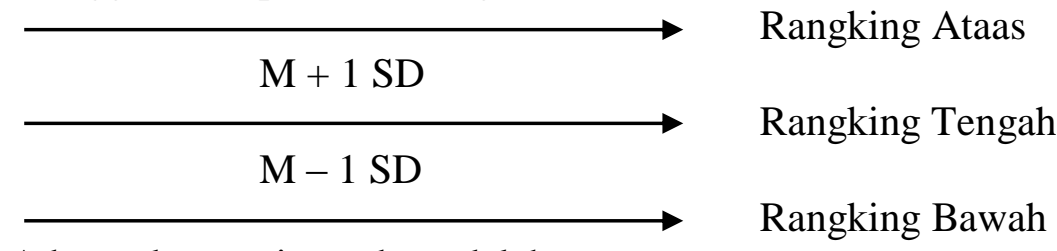

Adapun kategori tersebut adalah:

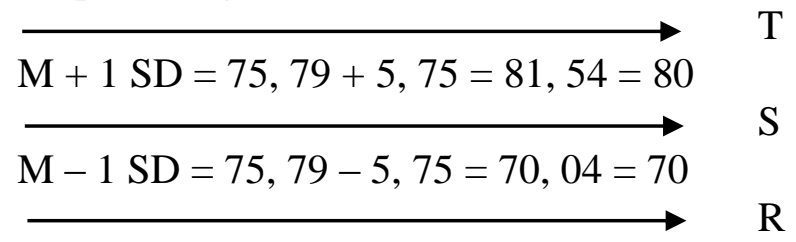

Penjelasan:

a. Nilai 80 ke atas adalah tinggi, berarti metode qiro'ati di Madrasah Ibtidaiyah Raudhatul Ulum Sakatiga tergolong tinggi.

b. Nilai antara 70 dan 79 adalah sedang, berarti metode qiro'ati di Madrasah Ibtidaiyah Raudhatul Ulum Sakatiga tergolong sedang.

c. Nilai 70 ke bawah adalah rendah, berarti metode qiro'ati di Madrasah Ibtidaiyah Raudhatul Ulum Sakatiga tergolong rendah.

Tabel 13

Distribusi Frekuensi dan Persentase TSR Metode Qiro'ati Madrasah Ibtidaiyah Raudhatul Ulum

\footnotetext{
${ }^{14} 1$ bid 160

${ }^{15}$.ibid 176
} 
Penrapan Metode Qiro'ati Dalam Meningkatkan Kefasihan Membaca Al-Qur'an Siswa Kelas VI Madrasah Ibtidaiyah Pondok Pesantren Raudhatul Ulum Sakatiga Kecamatan Inderalaya Kabupaten Ogan Ilir

Komputri Apria Santi

\begin{tabular}{|c||c|c|}
\hline Nilai Pre-Test Siswa & Frekuensi & Persentase \\
\hline Tinggi & 11 & $25,58 \%$ \\
Sedang & 28 & $65,11 \%$ \\
Rendah & 4 & $9,30 \%$ \\
Jumlah & 43 & $100 \%$ \\
\hline
\end{tabular}

Mengacu pada tabel di atas dapat dipahami, bahwa sebagian besar metode audiovisual adalah dalam kategorisedang, yaitu 28 orang responden $(65,11 \%)$. Responden yang mendapatkan nilai tinggi adalah 11 orang responden $(25,58 \%)$ dan mendapatkan nilai rendah 4 orang responden $(9,30 \%)$.

b. Analisis Kefasihan Membaca al-Qur'an

Untuk mengetahui kefasihan membaca al-Qur'an siswa, maka penulis mencoba menganalisis hasil belajar siswa melalui tes membaca al-Qur'an. Adapun tes membaca alQur'an siswa yang penulis peroleh akan direkapitulasi dan dianalisis dengan persentase statistik. Di bawah ini akan penulis sajikan data tes prestasi siswa-siswi sebagai berikut:

Dari tabel di atas dapat diketahui nilai-nilai siswa setelah diterapkannya media gambar, kemudian hasil atau nilai dari responden tersebut selanjutnya direkapitulasi dan dianalisis dengan mengunakan statistik sebagai berikut:

Variabel Y

85909095958590957575

70859510095100901008580

959080100959085908085

908595858080851009595

909590

Tabel 15

Distribusi Frekuensi Kefasihan Membaca al-Qur'an Siswa

\begin{tabular}{|c|c|cc|ccc|}
\hline $\mathrm{Y}$ & $\mathrm{f}$ & $\mathrm{Fy}$ & $\mathrm{Y}$ & $\mathrm{y}^{2}$ & $\mathrm{Fy}^{2}$ \\
\hline \hline 100 & 5 & 500 & 10,94 & 119,68 & 598,4 \\
95 & 11 & 1045 & 5,94 & 35,28 & 388,08 \\
90 & 10 & 900 & 0,94 & 0,88 & 8,8 \\
85 & 9 & 765 & $-4,06$ & 16,48 & 148,32 \\
80 & 5 & 400 & $-9,06$ & 82,08 & 410,4 \\
75 & 2 & 150 & $-14,06$ & 197,68 & 395,36 \\
70 & 1 & 70 & $-19,06$ & 363,28 & 363,28 \\
Total & $\mathrm{N}=43$ & $\sum \mathrm{y}^{2}=3830$ & $\sum \mathrm{y}=-28,42$ & $\sum \mathrm{y}^{2}=815,36$ & $\sum \mathrm{fx}^{2}=2312,64$ \\
\hline
\end{tabular}

1) Mencari Mean-nya dengan rumus ${ }^{16}$ :

$$
\begin{aligned}
& \mathrm{M}_{\mathrm{y}}=\frac{\sum \mathrm{fY}}{\mathrm{N}} \\
& \mathrm{M}_{\mathrm{y}}=\frac{3830}{43} \\
& \mathrm{M}_{\mathrm{y}}=89,06
\end{aligned}
$$

\footnotetext{
${ }^{16}$. Ibid 159
} 
Keterangan :

$\mathrm{M}_{\mathrm{y}} \quad=$ Nilai rata-rata dari variable $\mathrm{y}$

$\sum \mathrm{f}_{\mathrm{y}}=$ Jumlah hasil perkalian antara deviasi tiap-tiap interval $(\mathrm{Y})$ dengan frekuensi masing-masing interval yang bersangkutan.

$\mathrm{N}=$ Number of Cases

2) Mencari deviasi y dengan rumus ${ }^{17}: y=Y-M_{x}$

$$
\begin{aligned}
& \mathrm{y}=\mathrm{Y}-\mathrm{M}_{\mathrm{x}} \\
& \mathrm{y}=100-89,06 \\
& \mathrm{y}=10,91
\end{aligned}
$$

$\mathrm{y} \quad=$ Hasil dari pengurangan deviasi tiap-tiap interval $(\mathrm{Y})$ dengan nilai

rata-rata dari masing-masing variable y

$\mathrm{Y}=$ Variabel $\mathrm{y}$

$\mathrm{M}_{\mathrm{y}} \quad$ = Nilai rata-rata dari variable $\mathrm{y}$

3) Menguadratkan y sehingga diperoleh $y^{2}$, setelah itu di jumlahkan, sehingga diperoleh $\sum y^{2}=815,36$

4) Memperkalikan frekuensi dengan $y^{2}$, sehingga di peroleh $\sum \mathrm{fy}^{2}$, setelah itu dijumlahkan, di peroleh $\sum \mathrm{fy}^{2}=2312,64$

5) Mencari SD-nya dengan rumus ${ }^{18}$ :

$$
\begin{aligned}
& \mathrm{SD}_{\mathrm{y}}=\sqrt{\frac{\sum \mathrm{fy}^{2}}{\mathrm{~N}}} \\
& \mathrm{SD}_{\mathrm{y}}=\sqrt{\frac{2312,64}{43}} \\
& \mathrm{SD}_{\mathrm{y}}=\sqrt{53,78} \\
& \mathrm{SD}_{\mathrm{y}}=7,33
\end{aligned}
$$

\section{Keterangan:}

$\mathrm{SD}_{\mathrm{y}}=$ Deviasi standar y

$\sum \mathrm{fy}^{2}=$ Jumlah hasil perkalian antara frekuensi masing-masing sekor,

dengan deviasi sekor yang telah dikuadratkan.

$\mathrm{N}=$ Number of Cases

Setelah di ketahui mean skor dan standar deviasi skor tentang nilai Post-Test Siswa Kelas II A MI Raudhatul Ulum Ogan Ilir maka selanjutnya adalah menetapkan kategori TSR dengan menggunakan patokan sebagai berikut ${ }^{19}$ :

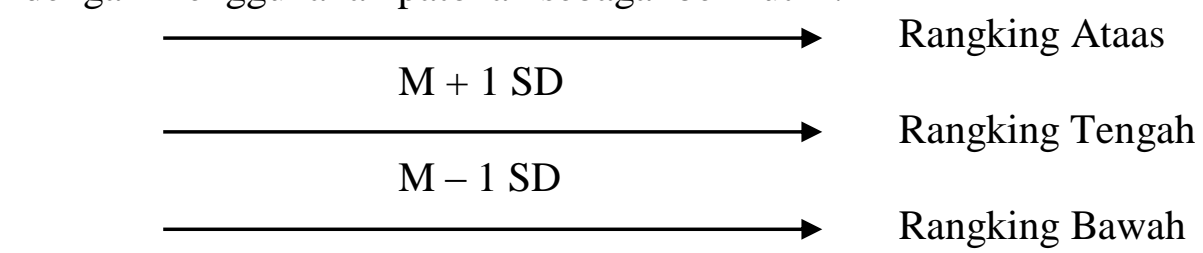

Adapun kategori tersebut adalah:

$$
\begin{array}{ll}
\stackrel{\mathrm{M}+1 \mathrm{SD}=89,06+7,33=96,39=100}{\longrightarrow} & \mathrm{T} \\
\stackrel{\mathrm{M}-1 \mathrm{SD}=89,06-7,33=81,73=80}{\longrightarrow} & \mathrm{S}
\end{array}
$$

\footnotetext{
${ }^{17}$ Ibid 158

${ }^{18}$ Ibid 160

${ }^{19}$ Ibid 176
} 
Penrapan Metode Qiro'ati Dalam Meningkatkan Kefasihan Membaca Al-Qur'an Siswa Kelas VI Madrasah Ibtidaiyah Pondok Pesantren Raudhatul Ulum Sakatiga Kecamatan Inderalaya Kabupaten Ogan Ilir

Komputri Apria Santi

Penjelasan:

a. Nilai 100 adalah tinggi, berarti kefasihan membaca al-Qur'an siswa kelas VI Madrasah Ibtidaiyah Raudhatul Ulum tergolong tinggi.

b. Nilai antara 80 dan 100 kategori sedang, berarti kefasihan membaca al-Qur'an siswa kelas VI Madrasah Ibtidaiyah Raudhatul Ulum tergolong sedang.

c. Nilai 80 ke bawah adalah rendah, berarti kefasihan membaca al-Qur'an siswa kelas VI Madrasah Ibtidaiyah Raudhatul Ulum tergolong rendah.

Tabel 16

Distribusi Frekuensi dan Persentase TSR Nilai Post-Test Siswa Kelas II A MI

Raudhatul Ulum

\begin{tabular}{|c|c|c|}
\hline Nilai Post-Test Siswa & Frekuensi & Persentase \\
\hline Tinggi & 5 & $11,62 \%$ \\
Sedang & 35 & $81,39 \%$ \\
Rendah & 3 & $6,97 \%$ \\
\hline Jumlah & 43 & $100 \%$ \\
\hline
\end{tabular}

Mengacu pada tabel di atas dapat dipahami, bahwa sebagian besar kefasihan membaca al-Qur'an adalah dalam kategorisedang, yaitu 35 orang responden $(81,39 \%)$. Responden yang mendapatkan nilai tinggi adalah 5 orang responden $(11,62 \%)$ dan mendapatkan nilai rendah 3 orang responden $(6,97 \%)$.

c. Analisis Kefasihan Membaca al-Qur'an

Untuk mengetahui kefasihan membaca al-Qur'an siswa, maka penulis mencoba menganalisis hasil belajar siswa melalui tes membaca al-Qur'an. Adapun tes membaca alQur'an siswa yang penulis peroleh akan direkapitulasi dan dianalisis dengan persentase statistik. Di bawah ini akan penulis sajikan data tes prestasi siswa-siswi sebagai berikut:

Dari tabel di atas dapat diketahui nilai-nilai siswa setelah diterapkannya media gambar, kemudian hasil atau nilai dari responden tersebut selanjutnya direkapitulasi dan dianalisis dengan mengunakan statistik sebagai berikut:

Variabel Y

85909095958590957575

70859510095100901008580

959080100959085908085

908595858080851009595

909590

Tabel 15

Distribusi Frekuensi Kefasihan Membaca al-Qur'an Siswa

\begin{tabular}{|c|c|c|c|c||c||}
\hline $\mathrm{Y}$ & $\mathrm{f}$ & $\mathrm{Fy}$ & $\mathrm{Y}$ & $\mathrm{y}^{2}$ & $\mathrm{Fy}^{2}$ \\
\hline \hline 100 & 5 & 500 & 10,94 & 119,68 & 598,4 \\
95 & 11 & 1045 & 5,94 & 35,28 & 388,08 \\
90 & 10 & 900 & 0,94 & 0,88 & 8,8 \\
85 & 9 & 765 & $-4,06$ & 16,48 & 148,32 \\
\hline
\end{tabular}




\begin{tabular}{|cccccc|}
\hline 80 & 5 & 400 & $-9,06$ & 82,08 & 410,4 \\
75 & 2 & 150 & $-14,06$ & 197,68 & 395,36 \\
70 & 1 & 70 & $-19,06$ & 363,28 & 363,28 \\
Total & $\mathrm{N}=43$ & $\sum \mathrm{y}^{2}=3830$ & $\sum \mathrm{y}=-28,42$ & $\sum \mathrm{y}^{2}=815,36$ & $\sum \mathrm{fx}^{2}=2312,64$ \\
\hline
\end{tabular}

1) Mencari Mean-nya dengan rumus ${ }^{20}$ :

Keterangan:

$$
\begin{aligned}
& \mathrm{M}_{\mathrm{y}}=\frac{\sum \mathrm{fY}}{\mathrm{N}} \\
& \mathrm{M}_{\mathrm{y}}=\frac{3830}{43} \\
& \mathrm{M}_{\mathrm{y}}=89,06
\end{aligned}
$$

$\mathrm{M}_{\mathrm{y}} \quad=$ Nilai rata-rata dari variable $\mathrm{y}$

$\sum \mathrm{f}_{\mathrm{y}} \quad=$ Jumlah hasil perkalian antara deviasi tiap-tiap interval $(\mathrm{Y})$ dengan frekuensi masing-masing interval yang bersangkutan.

$\mathrm{N}=$ Number of Cases

2) Mencari deviasi y dengan rumus ${ }^{21}: \mathrm{y}=\mathrm{Y}-\mathrm{M}_{\mathrm{x}}$

$$
\begin{aligned}
& y=Y-M_{x} \\
& y=100-89,06 \\
& y=10,91
\end{aligned}
$$

y $\quad=$ Hasil dari pengurangan deviasi tiap-tiap interval $(\mathrm{Y})$ dengan nilai rata-rata dari masing-masing variable y

$\mathrm{Y} \quad=$ Variabel $\mathrm{y}$

$\mathrm{M}_{\mathrm{y}} \quad=$ Nilai rata-rata dari variable $\mathrm{y}$

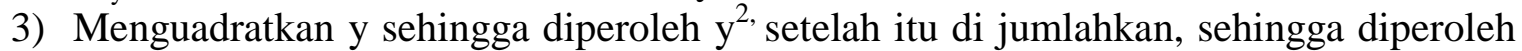
$\sum y^{2}=815,36$

4) Memperkalikan frekuensi dengan $y^{2}$, sehingga di peroleh $\sum \mathrm{fy}^{2}$, setelah itu dijumlahkan, di peroleh $\sum \mathrm{fy}^{2}=2312,64$

5) Mencari SD-nya dengan rumus ${ }^{22}$ :

Keterangan:

$$
\begin{aligned}
& \mathrm{SD}_{\mathrm{y}}=\sqrt{\frac{\sum \mathrm{ff}^{2}}{\mathrm{~N}}} \\
& \mathrm{SD}_{\mathrm{y}}=\sqrt{\frac{2312,64}{43}} \\
& \mathrm{SD}_{\mathrm{y}}=\sqrt{53,78} \\
& \mathrm{SD}_{\mathrm{y}}=7,33
\end{aligned}
$$

$\mathrm{SD}_{\mathrm{y}}=$ Deviasi standar y

$\sum \mathrm{fy}^{2}=$ Jumlah hasil perkalian antara frekuensi masing-masing sekor, dengandeviasi sekor yang telah dikuadratkan.

$\mathrm{N}=$ Number of Cases

Setelah di ketahui mean skor dan standar deviasi skor tentang nilai Post-Test Siswa Kelas II A MI Raudhatul Ulum Ogan Ilir maka selanjutnya adalah menetapkan kategori TSR dengan menggunakan patokan sebagai berikut ${ }^{23}$ :

\footnotetext{
${ }^{20}$. Ibid 159

${ }^{21}$ Ibid 158

${ }^{22}$ Ibid 160

${ }^{23}$ Ibid 176
} 
Penrapan Metode Qiro'ati Dalam Meningkatkan Kefasihan Membaca Al-Qur'an Siswa Kelas VI Madrasah Ibtidaiyah Pondok Pesantren Raudhatul Ulum Sakatiga Kecamatan Inderalaya Kabupaten Ogan Ilir

Komputri Apria Santi

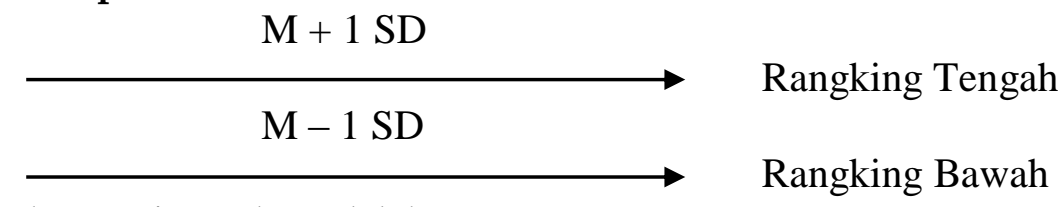

Adapun kategori tersebut adalah:

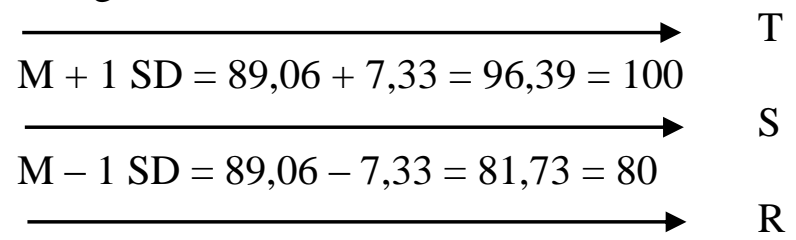

Penjelasan:

a. Nilai 100 adalah tinggi, berarti kefasihan membaca al-Qur'an siswa kelas VI Madrasah Ibtidaiyah Raudhatul Ulum tergolong tinggi.

b. Nilai antara 80 dan 100 kategori sedang, berarti kefasihan membaca al-Qur'an siswa kelas VI Madrasah Ibtidaiyah Raudhatul Ulum tergolong sedang.

c. Nilai 80 ke bawah adalah rendah, berarti kefasihan membaca al-Qur'an siswa kelas VI Madrasah Ibtidaiyah Raudhatul Ulum tergolong rendah.

Tabel 16

Distribusi Frekuensi dan Persentase TSR Nilai Post-Test Siswa Kelas II A MI Raudhatul Ulum

\begin{tabular}{|c|c|c|}
\hline Nilai Post-Test Siswa & Frekuensi & Persentase \\
\hline Tinggi & 5 & $11,62 \%$ \\
Sedang & 35 & $81,39 \%$ \\
Rendah & 3 & $6,97 \%$ \\
\hline Jumlah & 43 & $100 \%$ \\
\hline
\end{tabular}

Mengacu pada tabel di atas dapat dipahami, bahwa sebagian besar kefasihan membaca al-Qur'an adalah dalam kategorisedang, yaitu 35 orang responden $(81,39 \%)$. Responden yang mendapatkan nilai tinggi adalah 5 orang responden $(11,62 \%)$ dan mendapatkan nilai rendah 3 orang responden $(6,97 \%)$.

\section{Simpulan}

Berdasarkan hasil penelitian tentang penerapan metode qiro'ati dalam meningkatkan kefasihan membaca al-Qur'an siswa di kelas VI Madrasah Ibtidaiyah Raudhatul Ulum Sakatiga Kecamatan Indralaya Kabupaten Ogan Ilir, dapat disimpulkan sebagai berikut:

1. Penerapan metode qiro'ati dalam meningkatkan kefasihan membaca al-Qur'an siswa kelas VI MI Raudhatul Ulum Sakatiga adalah 11 orang responden tinggi (25,58\%), 28 orang responden sedang $(65,11 \%)$. 4 orang responden rendah $(9,30 \%)$. Maka dapat dikatakan bahwa penerapan metode qiro'ati dalam meningkatkan kefasihan membaca al-Qur'an adalah dalam kategori sedang yaitu $(65,11 \%)$.

2. Kefasihan membaca al-Qur'an siswa kelas VI Madrasah Ibtidaiyah Raudhatul Ulim Sakatiga adalah 5 orang responden tingi (11,62\%), 35 orang responden sedang $(81,39 \%)$. 3 orang responden rendah $(6,97 \%)$. Maka dapat dikatakan bahwa kefasihan siswa kelas VI Madrasah Ibtidaiyah Raudhatul Ulum Sakatiga Indralaya adalah dalam 
RAUDHAH Proud To Be Professionals qurnal Tarbiyakndamiyah

Volume 3 Nomor 2 Edisi Desember 2018

P-ISSN : 2541-3686

kategori sedang karena dari 43 siswa sebanyak 35 siswa atau 81,39\% yang mendapatkan skor dengan kualifikasi sedang.

\section{DAFTAR PUSTAKA}

Ahmad Saebani Beni, Metode Penelitian, 2008, Bandung: Pustaka Setia.

Ahmadi Abu, Uhbiyati Nur, IlmuPendidikan, 2003, Jakarta: PT Rineka Cipta.

Al-Atsqolani Ibnu Hajar, FathulBaari: Bi Syarh Shahih Al-Bukhori, (diterjemahkan oleh Amirudin), 2002, Jakarta: Pustaka Azam, Jilid 9.

Arikunto Suharsimi, Manajemen Penelitian, 2010, Jakarta: Rineka Cipta.

Arikunto Suharsimi, Prosedur Penelitian Suatu Pendekatan Praktik, 2006, Jakarta: Rineka Cipta.

Muchtar Heri Jauhari, Fikih Pendidikan, 2005, Bandung: Remaja Rosdakarya.

Sudiyono,M. Ilmu pendidikan Islam Jilid I,2009, Jakarta: PT Rineka Cipta.

Sudijono Anas, Pengantar Statistik Pendidikan, 2010, Jakarta: PT Raja Grafindo Persada.

Sugiyono, Statistik Untuk Peneletian,2009, Bandung: Alfabeta. 
Penrapan Metode Qiro'ati Dalam Meningkatkan Kefasihan Membaca Al-Qur'an Siswa Kelas VI Madrasah Ibtidaiyah Pondok Pesantren Raudhatul Ulum Sakatiga Kecamatan Inderalaya Kabupaten Ogan Ilir

Komputri Apria Santi 